Indonesian Journal of Physics and Nuclear Applications

Volume 2, Number 1, February 2017, p. 42-46

ISSN 2549-046X, (c) FSM UKSW Publication

\title{
Analysis of Safety and Health of Radiation Officer at Pilot Plant BNCT
}

\author{
Yuliana Dian N. ${ }^{\text {a*}}$, Soeparmi ${ }^{a}$, Y. Sardjono ${ }^{b}$ \\ dDepartment of Physics, Sebelas Maret University, J1. Ir. Soetami 36A Surakarta \\ 57126, Indonesia \\ ${ }^{\mathrm{b}}$ Center of Science and Accelerator Technology - PSTA Yogyakarta, Jl. Babarsari \\ 6101 ykbb Yogyakarta 55281, Indonesia
}

\begin{abstract}
Radiation is emission energy which derived from the process of transformation of atoms or nuclei unstable. The emission energy was emitted by a hoarse radiation, can cause changes in physical, chemical and biological material in its path so that the radiation worker should give special attention to health and safety during operate the installation using radiation. Limits opportunities for stochastic effects occur, or the risk resulting from the use of radiation that can be accepted by the public, and workers and prevent the occurrence of deterministic result of radiation harm to the individual. Equivalent dose of radiation received by workers or the public should not be beyond Dose Limit Value (NBD). This also applies to the radiation workers who operate tools for cancer therapy method using boron or Boron Neutron Capture Therapy (BNCT). BNCT is a method of new cancer therapies that are being developed, which combines methods of chemotherapy and radiotherapy. BNCT method utilizing ${ }^{10} \mathrm{~B}$ or boron compounds are likely to capture neutrons in thermal energy, which is produced by high - Linear Energy Transfer (LET). Medical examinations for radiation workers should be done regularly and follow the general principles of treatment work, namely the examination before work and after work. Threshold limit radiation exposure was 0.2 to $0.5 \mathrm{~Sv}$. When a person is exposed to radiation overdose, the investigation dosage needs to be done specifically include biological dosimetry.
\end{abstract}

Keywords BNCT, radiation safety, boron

\section{INTRODUCTION}

Radiation is emission energy which derived from the process of transformation of atoms or nuclei unstable. Energy propagation of radiation can occur through the material as well as space in the form of electromagnetic waves or particles. Energy radiation emitted by a radiation source, can cause changes in physical, chemical and biological material in its path (Filano R. et al, 2014), so that the radiation worker should give special attention to health and safety during operated the instalation that using radiation. The purpose of the radiation safety is to limit the chances of a result of stochastic or risk resulting from the use of radiation that can be accepted by the public, workers and prevent the occurrence of deterministic result of radiation harm to the individual. Equivalent dose of radiation received by workers or the public should not be beyond Dose Limit Value (NBD) (Pusdiklat BATAN, 2004).

Boron Neutron Capture Therapy (BNCT) is a New method of cancer therapies that are being developed, which combines methods of chemotherapy and radiotherapy. BNCT was first tested in 1951 by (Sweet et al, 1951). In 1989, from experiments conducted by $\mathrm{H}$. Sweet $\mathrm{W}$, that for epithermal neutron beam optimized for NCT, the effective energy should be $\leq-2 \mathrm{keV}$. BNCT clinical studies by KURRI started in February 1990. Initially BNCT in this institution is only used for malignant brain cancer. Along with the development of technology and various studies now BNCT can be used for almost all types of cancer. Along with the development of the 
reactor-based BNCT clinical studies, also conducted clinical studies with acceleratorbased BNCT (Sakurai Y. et al, 2015).

NCT method utilizing ${ }^{10} \mathrm{~B}$ or boron compounds are likely to be capture neutrons in thermal energy, which is produced by hight Linear Energy Transfer (LET) that is equal to $0.025 \mathrm{eV}$ is used in this therapy and ${ }^{10} \mathrm{~B}$ will turn into ${ }^{11} \mathrm{~B}$ unstable so that it will happen disintegration emits alpha particles and the core ${ }^{7} \mathrm{Li}$ (T. Mitsumoto et al, 2013). Boron is a nonmetallic element of group III A of the periodic table that has two stable isotopes naturally namely ${ }^{11} \mathrm{~B}$ and ${ }^{10} \mathrm{~B}$ are quite abundant in nature. At standard temperatures boron is a poor electrical conductor but is a good conductor at high temperatures. Boron is not present in nature in its elemental form. Boron is usually found combined in borax, boric acid, kernite, ulexite, colemanite and borates.

The advantage of the method is in a concentration BNCT boron compound is nontoxic. The time interval between drug administration and the neutron irradiation can be used to maximize the absorption of boron compounds. A particles can damage both cancerous cells that are splitting or not splitting (IAEA 2001; Suzuki M. et al., 2014; Kageji T. et al., 2014; Y. Tetsuya et al., 2014; Ana J. Molinari et al., 2015; Heber, E. M. et al., 2014; Sun, T. et al., 2013; Kawabata S. et al., 2013).

\section{MATERIALS AND METHODS}

\subsection{Radiation Protection in Officer}

Occupational radiation exposure can occur as a result of various human activities. Sources of radiation (radioisotopes) can be divided into two, the natural sources of radiation in the form of radioactive substances and artificial radiation sources, and type of radiation can be divided into a charged particle radiation, radiation uncharged particles and electromagnetic waves or photons. Detection, characterization and effect of radiation is very dependent on the interaction of radiation with matter/materials. Radiation sources can be divided into two, namely the natural sources of radiation and artificial radiation sources. The radiation source itself can be identified as the source in the form of radioactive substances and sources such as engines, such as aircraft X-rays, accelerators, and nuclear reactors (Senduk P. et $a l, 2015$; Pusdiklat BATAN, 2004).

The requirements for achieving the objectives and principles set forth in the Safety Fundamentals, including requirements protection for workers exposed to radiation, contained in the International Basic Safety Standards for Protection against Ionizing Radiation and for the Safety of Radiaton Sources (the Basic Safety Standards or BSS) (IAEA RS-G-1.1,1999). Radiation protection is one component that must be considered to protect the health and safety of workers. Radiation protection program should be established and managed in conjunction with health and safety programs other. The main focus of your safety is to protect workers in carrying out practical activities under control. When exposed to radiation exposure beyond reasonable, limits of action in determining the specific circumstances in which the protective measures and countermeasures need to be implemented.

\subsection{Dose Limitation}

Awarding limit action will be given when the value of the dose rate or multiplication several times the level of exposure to gamma of $0.5 \mu \mathrm{Sv} / \mathrm{h}$ during one year of work (2000 hours) and reach speeds of an effective dose of $1 \mathrm{mSv}$. Whereas, exposure limit value for whole body dose of 50 $\mathrm{mSv}$ (5000 mrem) per year. Dose restrictions for 
members of the public for the rest of the body $5 \mathrm{mSv}(500 \mathrm{mrem})$ in a year. Every employer shall ensure the installation of radiation contribution coming from the installation on the members of society as a whole as low as possible and should be re-examined (IAEA RS-G-1.1,1999; Pusdiklat BATAN, 2004). Equivalent dose of radiation received by workers or the public should not be beyond Dose Limit Value (NBD) established the Supervisory Board.

The dosimetric quantities recommended for radiological protection purposes, and in which the dose limits are expressed in the BSS, are the effective dose $\mathrm{E}$ and the equivalent dose HT in tissue or organ T. The basic physical quantities include the particle fluence $\varphi$, the kerma $\mathrm{K}$ and the absorbed dose D (IAEA RS-G-1.1,1999; IAEA RS-G-1.3,1999).

\subsection{Health Monitoring}

Health controls designed to monitor the fitness beginning and continuation of fitness workers to tasks assigned to them as well as to provide initial information that could be used in case of accidental exposure to toxic materials or occupational diseases which allows about it, and to support the management of workers were exposed to doses excess. Dose in organs in the body cannot be measured directly, so the number of practical, measured outside the body, is required. For the field of radiation outside the body, a measurable amount, called the number of operations, has been recommended by the International Commission on Radiation Units and Measurements. Medical examinations for workers exposed to occupational exposure should follow the general principles of treatment work. There should be a medical examination before starting work and regular assessments. Periodic re-examination should be focused on the confirmation of the absence of clinical conditions that can give rise to prejudices about workers' health when working with radiation.

- Areas of moderate radiation, which is the area that allows a person receiving a dose of $15 \mathrm{mSv}$ or more and less than $50 \mathrm{mSv}$ in a year for the whole body or a value corresponding to a particular organ.

- Areas of high radiation, which is an area that allows a person receives a dose of $50 \mathrm{mSv}$ or more in a year or a value corresponding to a particular organ (IAEA RS-G-1.1,1999; Pusdiklat BATAN, 2004).

Dose highly exceed dose limits (eg 0.2 to 0.5 $\mathrm{Sv}$ or higher) will require the investigation of the dose typically include biological dosimetry (abrasion analysis of chromosomes in somatic cells, terutapa lymphocytes) and further diagnostic broader or medical treatment may be needed. IAEA RS-G-1.1,1999)

\section{RESULT AND DISCUSSION}

Health and safety in relation to the radiation needs special attention. Exposure to radiation received, can occur as a result of human activity. Detection, characterization and effect of radiation is very dependent on the interaction of radiation with matter/materials. The radiant energy emitted by a hoarse radiation, can cause changes in physical, chemical and biological material in its path. Radiation protection is one component that must be considered to protect the health and safety of workers. Radiation protection program should be established and managed along with the health and safety of other programs. When exposed to radiation beyond reasonable famine, limit action in determining the specific circumstances in which the protective measures 
and countermeasures need to be implemented.

Medical examinations for radiation workers should be done regularly and follow the general principles of treatment work, namely the examination before work and after work. Awarding limit action will be given when the value of the dose rate or multiplication several times the level of exposure to gamma of $0.5 \mu \mathrm{Sv} / \mathrm{h}$ during one year of work (2000 hours) and reach speeds of an effective dose of $1 \mathrm{mSv}$. Whereas, the exposure limit value for whole-body dose of $50 \mathrm{mSv}$ (5000 mrem) per year. Dose restrictions for members of the public for the rest of the body $5 \mathrm{mSv}$ (500 mrem) in a year.

\section{CONCLUSION AND REMARKS}

The radiant energy emitted by a radiation source, can cause changes in physical, chemical and biological material in its path. Medical examinations for radiation workers should be done regularly and follow the general principles of treatment work, namely the examination before work and after work. Threshold limit radiation exposure was 0.2 to $0.5 \mathrm{~Sv}$. When a person is exposed to radiation overdose, the investigation dosage needs to be done specifically include biological dosimetry. In addition to the radiation safety of the facility also needs to be considered.

\section{ACKNOWLEDGMENT}

Thanks to The Hed of PSTA, which has given permition for condacting reaserch, to Prof. Dra. Suparmi, M.A, Ph.D and Prof. Ir. Yohannes Sardjono for supervising in the reasech. The autors suggest the safety and health radiation officer is very important. Beside that, we must also to consider the safety of the installation of radiation.

\section{REFERENCES}

Ana J. Molinari, I Thorp, Silvia, M Portu, A et al. (2014).; Assessing advantages of sequential boron neutron capture therapy (BNCT) in an oral cancer model with normalized blood vessels; acta oncological; 54: 99-106, 2015Heber, E. M. et al.,

Filano R., Hidayanto E., Arifin Z. (2014). Analisa Tingkat Kontaminasi Dosis Nuklir dan Laju Paparan Radiasi Pada Instalasa Kedokteran Nuklir, Youngster Physics Journal, Vol. 3 hlm. 317-328.

International Atomik Energy Agency. (1999). IAEA Savety Standart Series RS-G-1.1: Occupational Radiation Protection

International Atomik Energy Agency. (1999). IAEA Savety Standart Series, Assessment of Occupational Exposure Due to External Source of Radiation RS-G-1.3,1999

International Atomik Energy Agency. (2001). Current Status of Neutron Capture Therapy, IAEA-TECDOC-1223. Vienna

Kageji T., Nagahiro S., Mizobuchi Y., Matsuzaki K., Nakagawa Y., and Kumada H. (2014). Boron neutron capture therapy (BNCT) for newly-diagnosed glioblastoma : Comparison of clinical results obtained with BNCT and conventional treatment.; The Journal of Medical Investigation, Vol. 61, hlm. 254-263.

Kawabata S, Hiramatsu R, Kuroiwa T, Ono K, Shin-Ichi M. (2013). Boron Neutron Capture Therapy for Recurrent High-Grade Meningiomas; J Neurosurg, Vol. 119, hlm. 837-844.

Pusat Pendidikan dan Pelatihan Badan Tenaga Nuklir Nasional. (2004). Dokumen Proteksi Radiasi, BadanTenaga Nuklir Nasional.

Sakurai Y., H. Tanaka, T. Takata, N. Fujimoto, M. Suzuki, S. Masunaga,Y. Kinashi, N. Kondo, M. Narabayashi, Y. Nakagawa, T. Watanabe, Koji Ono and A. Maruhashi.( 2015). Advances in Boron Neutron Capture Therapy (BNCT) at Kyoto University From 
Reactor-based BNCT to Acceleratorbased BNCT, Journal of the Korean Physical Society, Vol. 67, No. 1, halm. 76 81Mitsumoto T., Yajima S., Tsutsui H., Ogasawara T., Fujita K., Tanaka H., Sakurai Y., Maruhashi A. (2013). Cyclotron-Based Neutron Source For BNCT, Aplication of Accelerators in Research and Industry, AIP Conf. Proc. 1525, hlm. 319-322.

Senduk P., Danes V. R., Rumampuk J. F. (2015). Penggunaan Radioisotop pada Deteksi Dini Penyakit Kanker, Juenal eBiomedik, Vol. 2, hlm. 620-623.

Sun T., Zhang Z., Bin Li, Chen G., Xueshun Xie, Yongxin Wei, Jie Wu, Youxin Zhou and Ziwei Du. (2013). Boron Neutron Capture Therapy Induces Cell Cycle Arrest and Cell Apoptosis of Glioma Stem/Progenitor Cell In Vitro; Radiation Oncology, 8:195

Suzuki M., Kato I., Aihara T., Hiratsuka J., Yoshimura K., Niimi M., Kimura Y., Ariyoshi Y., Haginomori S., Sakurai Y., Kinashi Y., Masunaga S., Fukushima M., Ono K. And Maruhashi A. (2014). Boron neutron capture therapy outcomes for advanced or recurrent head and neck cancer. Journal of Radiation Research, 55, hlm. 146-153.

Sweet W H. JAVID M. (1951) The possible use of slow neutrons plus boron"' in therapy of intracranial tumors. Trcrrr.strciio,r.s ofrlic A/ticricwi Neitro/o,qiccil Associririori. 76th Annual Mecting. pp. $60-63$

Y. Tetsuya, T. Koji, Nakai K et al. (2013). Boron eutron Capture Therapy for Brain Tumors, Transl Cancer Res.;2(2):80-86 